Mohd Nazri Yusuf ${ }^{1, a}$, Wan Emri Wan Abdul Rahaman ${ }^{7,0}$, Yupiter HP Manurung ${ }^{1, c}$, Micheal Stoschka ${ }^{2, a}$, Muhammad Azim Suhaimi ${ }^{1 e}$, Ahmad Afiq Azim Rusli ${ }^{1, f}$

\title{
Tensile stress-strain analysis of resistance spot weld using non- linear FEM with experimental verification
}

\section{Analiza zavisnosti zateznih napona - deformacija tačkasto elktrootporno zavarenog spoja primenom nelinearne metode konačnih elemenata sa eksperimentalnom verifikacijom}

Originalni naučni rad / Original scientific paper

Rad je u izvornom obliku objavljen u okviru 72. IIW godišnje Skupštine $i$ međunarodne konferencije održane u BratislaviSlovačka 07-12. Jula 2019

\section{Rad primljen / Paper received:}

Januar 2021.

Prevod izvornog rada na srpski jezik: A. Mitrašinović

Ključne reči: Tačkasto zavarivanje, analiza konačnih elemenata

\section{Abstract}

This research presents an investigation on stressstrain behaviour induced by resistance spot weld followed by tensile shear test. The spot weld is modelled according to standardized dimension for tensile test with main material properties of $\mathrm{Cu}$ as electrode and low carbon steel S235 as plates with $1 \mathrm{~mm}$ thickness which include electric conductivity, resistivity and heat transfer coefficient for solid body as well as contact interface. The FEM simulation is conducted using the process parameter of current between $6,000 \mathrm{~A}$ to $15,000 \mathrm{~A}$, force at $5,000 \mathrm{~N}$ and different stages of time following the welding process and tensile test which is carried out after releasing both of the electrodes and material reaches the initial temperature with contact clamp velocity of $5 \mathrm{~mm} / \mathrm{min}$. To ensure the glued elements between the plates, subroutine in MSC Marc/Mentat is used in the simulation with defined temperature. The outcome of simulation results will be verified with series of experiment. It is expected that simulation will give good agreement compared to experimental analysis within acceptable range of error.

\section{Introduction}

Resistance spot welding is one of the most applied joining techniques for metal sheet which widely used in many industries such as automotive. Approximately more than 4,000 individual spot
Adresa autora / Author's address:

1 Faculty of Mechanical Engineering, Universiti Teknologi MARA, Shah Alam, Malaysia

2 Christian Doppler Laboratory for Manufacturing Process based Component Design, Montanuniversität Leoben, Leoben, Austria

anazdya13@gmail.com,

bemriwan80@gmail.com,

cyupiter.manurung@gmail.com,

micheal.stoschka@unileoben.ac.at,

eazimsuhaimi95@yahoo.com,

faafiqhazim@gmail.com

Keywords: Spot welding, finite element analysis

\section{Rezime}

Ovo istraživanje predstavlja analizu ponašanja napona - deformacija elektootporno tačkasto zavarenog spoja, pri ispitivanju smicajnim zatezanjem. Tačkasti zavareni spoj je modeliran u skladu sa standardizovanim dimenzijama za ispitivanje zatezanjem, sa glavnim osobinama $\mathrm{Cu}$ kao materijala elektrode i nisko-ugljeničnog čelika S235 kao ploče debljine $1 \mathrm{~mm}$, koje uključuju električnu provodljivost, otpornost i koeficijent prenosa toplote za čvrsto telo kao i za kontaktne površine. Simulacija metodom konačnih elemenata (MKE) je sprovodena korišćenjem procesnih parametra: struje između $6000 \mathrm{~A}$ i $15000 \mathrm{~A}$, sile od $5000 \mathrm{~N}$ i različitih vremenskih perioda procesa zavarivanja i zatim ispitivanja zatezanjem koja su vršena nakon oslobađanja elektroda i kada materijal dostigne početnu temperaturu, sa brzinom kontaktnog steznja od $5 \mathrm{~mm} / \mathrm{min}$. Da bi se obezbedilo prijanjanje dodirnih elemenata između ploča, u simulaciji je korišćen potprogram u MSC Marc / Mentat sa definisanim temperaturama. Rezultati simulacije biće verifikovani serijom eksperimenata. Očekuje se da će simulacija dati dobro slaganje sa eksperimentalnom analizom sa prihvatljivim opsegom grešake.

1. Uvod

Elektrootporno tačkasto zavarivanje je jedna od najčešće primenjivanih tehnika spajanja metalnih limova koja se široko koristi u mnogim industrijama poput automobilske. Otprilike više od 4,000 
welds are applied to assemble a vehicle body and the related parts [1].

Spot welded joint is made by the combination of heat, pressure and time. The fusion occurred through weld nugget, which is formed as a result of large amount of heat generated due to high contact resistance to the high current flow at low voltage. The spot welded joint quality is subjected to electric current flow time, sheet thickness, the amount of welding current, cross-sectional area, and contacts surfaces of the welding tips. [2].

The key advantage of spot welding technique is time and cost efficient as well as highly suitable for automation. In vehicle design, strength of spot welded joint is among of safey factor to be considered in crash test analysis [3]. In spite of rapid change in welding technology over the past decades, resistance spot welding is remain practical as a subject of interest by many researchers.

The spot welded joint quality is commonly studied experimentally through various method of test such as microstructure examination, shear testing, cross tension testing, peel testing and hardness test but experimental approach alone will be too costly and time inefficient. To reduce cost and time, simulation approach through mathematical model is oftenly used by researchers and engineers to visualize and represent the actual problem. Finite Element Method (FEM) was known as one of efficient methods to analyze different phenomenon of engineering problem with capability to produce a much more detailed set of results compared with experimental investigations [4]. In the present study, a non-linear FE based software MSC.Marc was used to simulate the resistance spot welding process and a tensile test is modelled for comparison with the actual experiment [5].

\section{Resistance Spot Welding Process - A Fundamental Theory and FEM}

Resistance spot welding is a process in which faying surfaces are joined in one or more spots by resistance to the flow of electric current through work pieces that are held together under force by electrodes [6]. Spot welding is operating based on amount of current that passes through the work piece, pressure of electrode on the work piece, time of current flow through the work piece and area of electrode tip with the work piece. The key parameters of spot welding process are electrode force, diameter of electrode contact surface, squeeze time, weld time, hold time and weld current. zavarenih spojeva je neophodno za formiranje jedne karoserije vozila i pripadajućih delova [1].

Tačkasti zavareni spoj se izrađuje kombinacijom toplote, pritiska i vremena. Spoj se ostvaruje formiranjem sočivastog šava, koji nastaje kao rezultat povećanja količine toplote usled visokog otpora protoku struje niskog napona. Kvalitet zavarenih spojeva zavisi od vremena protoka električne struje, debljine ploča koje se zavaruju, jačini struje zavarivanja, površine poprečnog preseka, i kontaktnih površina elektroda za zavarivanje [2]. Ključne prednosti tehnike tačkastog zavarivanja su niski troškovi i brzina, i izuzetna podobnost za automatizaciju procesa. Prilikom projektovanja vozila, čvrstoća tačkasto zavarenog spoja je jedan od najvažnijih sigurnosnih faktora koji se uzimaju u obzir u analizi testa sudara [3]. Uprkos brzim promenama tehnologije zavarivanja tokom poslednjih decenija, tačkasto zavarivanje i dalje ostaje predmet interesovanja mnogih istraživača. Kvalitet zavarenih spojeva obično se proučava različitim metodama ispitivanja, kao što su ispitivanje mikrostrukture, ispitivanje smicanjem, ispitivanje poprečnog zatezanja i ispitivanje tvrdoće. Samo eksperimentalni pristupi analizama su skupi i vremenski neefikasani. Da bi se smanjili troškovi i vreme, istraživači i inženjeri često koriste simulacioni pristup kroz matematički model kako bi vizualizovali i predstavili stvarni problem. U poređenju sa eksperimentalnim istraživanjima, metoda konačnih elemenata (MKE) je poznata kao jedna od efikasnih metoda za analizu različitih inženjerskih problema sa mogućnošću da pruži veći broj detaljnijih rezultata [4]. U ovoj studiji, nelinearni softver konačnih elemenata (KE) zasnovan na softveru MSC.Marc, je korišćen za simulaciju procesa elektrootpornog tačkastog zavarivanja i modelirano je ispitivanje zatezanjem radi poređenja sa eksperimentom [5].

\section{Proces elktrootpornog tačkastog zavarivanja - osnovna teorija i MKE}

Otporno tačkasto zavarivanje je postupak u kojem se radne površine spajaju na jednom ili više mesta usled otpora materijala na protok električne struje kroz radne komade koji su elektrodama pričvršćeni jedni za druge [6]. Tačkasto zavarivanje deluje na osnovu količine struje koja prolazi kroz radni predmet, pritiska elektrode na radni predmet, vremena protoka struje kroz radni predmet i površine vrha elektrode sa radnim delom. Ključni parametri postupka tačkastog zavarivanja su sila i trajanje stezanja, prečnik kontaktne površine elektrode, trajanje zavarivanja i struja zavarivanja. 
Fig. 1 illustrates the basic spot welding principle

Slika 1 ilustruje osnovni princip tačkastog zavarivanja.

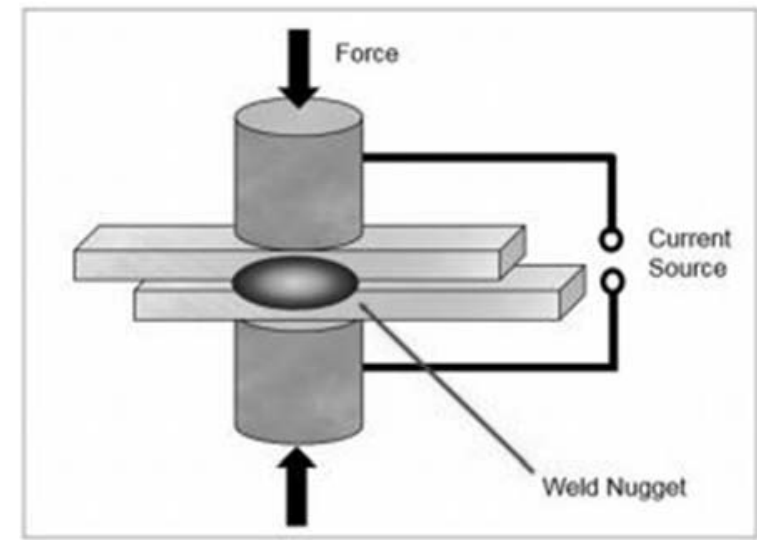

Figure 1. Basic principle of resistance spot welding

Slika 1. Osnovni princip elektrootpornog tačkastog zavarivanja

According to Ohm's law,

$E=I R$

Where I is the current, $E$ is voltage drop across the electrodes and $R$ is the resistance through the material in ohms. $R$ is the summation of the contact resistances and the resistance of the work to be welded. Therefore, for a given value of $R$, the magnitude of $I$ is determined by $E$. Current to the primary of the transformer is controlled which, in turn, determines the current delivered to a weld of a given resistance [7]. The total heat in watt-seconds generated in the work being welded and in the welding electrodes is expressed by the formula:

$H=I^{2} R T$.

$H=I E T$.

( $\mathrm{T}$ is time in seconds)

The welding cycle is divided into four time segments: squeeze, heat/ weld, hold and off [8] as shown in Fig. 2.
Prema Omovom zakonu

$E=I R$

gde je I stuja, $E$ je pad napona duž elektrode i $R$ je otpor kroz materijal. $R$ (u Om-ima) je zbir svih kontaktnih otpora i otpora radnog predmeta koji se zavaruje. Prema tome, za datu vrednost $R$, veličina I je određena sa $E$. Struja ka primarnom transformatoru je kontrolisana što zauzvrat određuje jačinu isporučene struje na dati zavereni spoj [7]. Ukupna toplota u vat-sekundama stvorena na elektrodama tokom procesa zavarivanja izražava se formulom:

$H=I^{2} R T$.

$H=I E T$.

( $T$ je vreme uzraženo u sekundama)

Ciklus zavarivanja je podeljen u četiri vremenska segmenta: pričvršćivanje, zagrevanje/zavarivanje, zadržavanje i isključivanje [8] kako je prikazano na Slici 2.

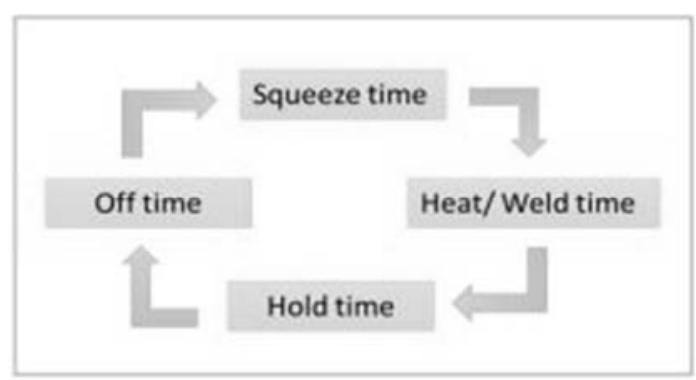

Figure 2. Spot welding cycle

Slika 2. Ciklus tačkastog zavarivanja

- Squeeze time: time between pressure application and weld.

- Heat or weld time: Interval of welding current flows through the circuit (60 cycles $=1$ second).

- Hold time: welding current is off, the electrode force is held
- Trajanje stezanja: vreme između primene pritiska stezanja i trenutka zavarivanja.

- Trajanje zagrevanja ili zavarivanja: Interval struje zavarivanja (60 ciklusa = 1 sekunda).

- Trajanje zadržavanja: struja zavarivanja je isključena, dok pritiskajuća sila elektroda je aktivna. 
- Off-time: interval from the end of the hold time until the beginning of the squeeze time for the next cycle. Retract the electrodes, remove or reposition work piece.

Finite element analysis (FEA) is a mathematical method used to resolve engineering problems. However, some of FEA based software may not able to accurately simulate resistance spot welding process as it governed by electricalthermal, mechanical and metallurgical phenomena. To resolve these complex problems, a Finite Element based software MSC.Marc were used. It is difficult to simulate the RSW process because three different physical phenomena are interacting with each other. The model takes the following physical and metallurgical interactions into consideration in the simulations, interaction between the electrokinetics and heat transfer via the Joule effect, heat transfer and phase transformations through latent heat and heat transfer, electro-kinetics, and mechanical behaviour via contact conditions [9].

The welding process starts with analysing the squeeze cycle in which electrode force is applied to the electrodes. The results of this mechanical analysis include initial deformations and contact area, which serve in an electro thermal analysis. At this point, the temperature distribution of Joule heating is calculated for an increment from the fully coupled electrical thermal FEA. In the electrically thermally coupled analysis the electrical and thermal boundary conditions are utilized in the model of a house. Then the calculations of Joule heating at the sheet-sheet and electrodesheet faying surfaces, as well as in the base material and electrode have to be done. As a consequence, the temperature distributions are held in the first increment and sent to the mechanical analysis as a nodal thermal load. Contact pressure and deformations are the consequences of mechanical analysis that obtains a new contact condition. Thus, the mechanical results are transmitted to the electrothermal analysis to update contact conditions for the next increment analysis. This loop goes on until the welding time is finished [10].

The mesh is graded from fine to coarse, according to the expected reduction in temperature gradient on moving away from the heat source. Solid elements were used to simulate the thermo-elasticplastic behaviour of the sheets and electrodes. Contacts were employed to simulate the contact areas. In that respect are three contact fields in the exemplar according to Sun, D., Zhang, Y., Liu, Y., $\mathrm{Gu}, \mathrm{X}$., \& Li, H. [11]. Fig. 3 below shows the mesh generation of a developed model. Contact area 1 and 2 shows the electrode-work piece interface and
Vreme isključenja: interval od kraja perioda zadržavanja do početka vremena stiskanja za sledeći ciklus. Povlačenje elektrode, uklanjanje i zamena radnog predmeta.

Analiza konačnih elemenata (MKE) je matematička metoda koja se koristi za rešavanje inženjerskih problema. Međutim, neki od softvera zasnovanih na MKE ne mogu precizno da simuliraju postupak tačkastog zavarivanja, zato što su ti procesi vođeni složenim električno-termičkim, mehaničkim i metalurškim fenomenima. Da bi se rešili ovi složeni problemi korišćen je MSC.Marc softver zasnovan na konačnim elementima. Teško je simulirati proces elktrootpornog tačkastog zavarivanja jer tri različita fizička fenomena su međusobno povezana. Ovaj kompjuterski model uzima u obzir sledeće fizičke i metalurške interakcije tokom simulacije procesa: interakciju između elektro-kinetike i prenosa toplote pomoću Joule-ovog efekta, prenos toplote i fazne transformacije uzimajući u obzir latentnu toplotu i prenos toplote, elektro-kinetiku, i mehaničko ponašanje preko uslova na kontaktima [9].

Proces zavarivanja započinje analizom ciklusa pričvršćivanja u kome elektrode pritiskaju radni predmet. Rezultati mehaničke analize uključuju početne deformacije i kontaktnu površinu, koje omogućuju elektrotermičku analizu. Zatim se izračunava raspodela temperature usled Džulovog grejanja za svaki priraštaj povezane električne i termičke MKE analize. U električno-termički povezanoj analizi električni i toplotni granični uslovi su upotrebljeni u ovom modelu. Tada se izvršavaju proračuni Joul-ovog zagrevanja na kontaktnim površinama između dva radna predmeta kao i na površini radni predmet - elektroda. Izračunata raspodela temperature u prvom koraku se koristi za mehaničku analizu kao nodalno termičko opterećenje. Promena kontaktnog pritisaka i deformacije su posledice mehaničke analize koja određuje novo kontaktnog stanja. Dakle, mehanički rezultati se vraćaju u elektro-termalnu analizu kako bi se ažurirali uslovi kontakta za sledeću inkrementalnu analizu. Ova petlja traje sve dok se ne dostigne zadato vreme trajanja zavarivanja [10]. Mreža koja pokriva radni komad, je razvrstana od fine do grube sa udaljenjem od izvora toplote, zbog očekivanog smanjenja gradijenta temperature $u$ tom pravcu. Puni elementi su korišćeni za simulaciju termo-elastično-plastičnog ponašanja radnih predmeta i elektroda. Simulacija kontaktnih područja je izvršena na kontaktima. U tom pogledu su korišćena tri kontaktna polja u primeru Sun, D., Zhang, Y., Liu, Y., Gu, X., \& Li, H. [11]. Slika 3. prikazije formiranje mreže u razvijenom modelu. 
contact area 3 represents the faying surface. In order to obtain a reliable results, fine meshes were created near these contact areas, while the meshes of other areas were relatively coarse.
Kontaktne površine 1 i 2 pokazuju interfejs između elektrode i radnog predmeta, a kontaktna površina 3 predstavlja naslanjajuću površinu radnog predmeta. Da bi se dobili pouzdani rezultati, u blizini ovih kontaktnih područja stvorena je fina mreža, dok su mreže ostalih područja relativno grube.

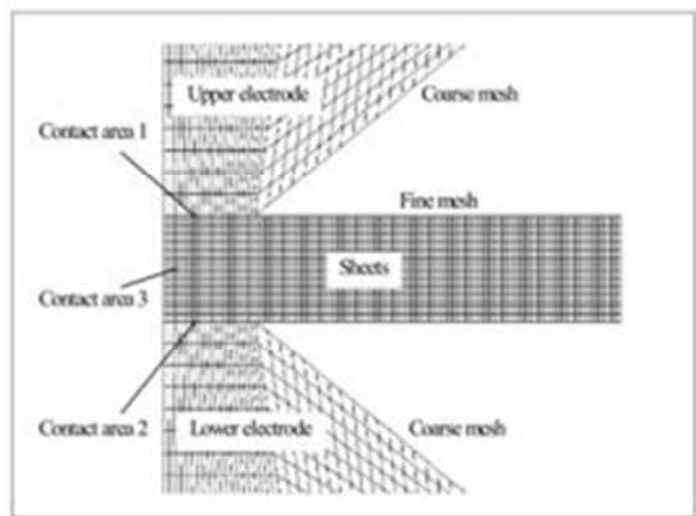

Figure 3. The mesh generation of a developed model Slika 3. Formiranje mreže razvijenog modela

Fig. 4 shows the temperature changing histories at three locations: the centre of nugget, the centre of the electrode and work piece interface and the edge of the electrode. In this analysis, the temperature field was taken as Finite Element Method (FEM) nodal load and applied on every node of the model.
Slika 4 prikazuje istorijat promena temperature na tri lokacije: centru sočivastog šava, centru elektrode i dodira radnog predmeta i ivice elektrode. U ovoj analizi temperaturno polje je uzeto kao čvorno opterećenje metode konačnih elemenata (MKE) i primenjeno na svaki čvor modela.

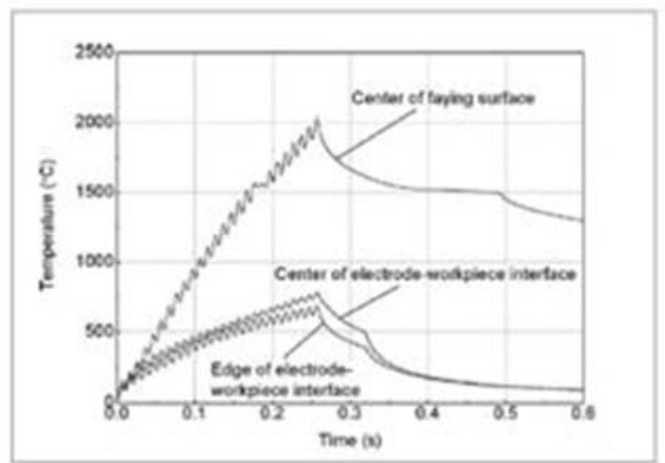

Figure 4 Temperature histories at three locations

Slika 4. Temperaturne istorije na tri lokacije

Generally, contact resistance decreases with increasing temperature. At the metal surface many impurities are available (i.e. Oil, dirt, and oxides). As temperature increases, few of these impurities burn with the metal in initial cycles. These impurities softened at high temperature and this causes decrease in contact resistance with an increase in temperature [12].

A theory of plasticity is developed for a material which is initially isotropic and fulfils the maximum shear stress initial yield condition. It is proven that the most general piecewise linear theory depends upon 5 material constants. These admit the initial
Generalno, otpor na kontaktima opada sa porastom temperature. Na metalnoj površini postoje mnoge nečistoće (npr. ulje, prljavština i oksidi). Sa povećanjem temperature u početnim ciklusima mala količina ovih nečistoća sagoreva sa metalom. Ove nečistoće omekšavaju sa povećanjem temperature i prouzrokuju smanjenje otpora na kontaktima [12].

Teorija plastičnosti je primenjena na materijalu koji je u početku izotropan i zadovoljava maksimalni napon smicanja pri početnim uslovima popuštanja. Poznato je da najopštija linearna teorija zavisi od 5 konstanti materijala. Te konstante su početni napon 
yield stress, the rate of hardening, and three constants which identify the effect of hardening upon the condition for further yielding [13]. The general form of power-law stress-strain curve model has the following equation $\sigma=A \varepsilon^{\wedge} \mathrm{n}$, whereby $n$ is the strain hardening coefficient, and $A$ is the constant which are adjusted to best fit measured stress-strain data. The value of $n$ should be in the range $0-1$ in order to model concavedownward behaviour [14]. The power - law model is used extensively because of its mathematical simplicity, however, only certain types of stress strain behaviour can be modelled with it.

Plasticity can also be applied to analyse weld residual stresses and deformation. At that point is exit unique relationship between the inherent shrinkage strains and the weld residual stresses and deformation. This analysis can be expanded to incorporate the effects of initial deformation, interaction between neighbouring welds, welding sequence, and also structural stiffness. To use the plasticity in practical situations, normally it requires a mock up welding test calibrating the engineering solutions for characteristic process parameters, material non-linearities and geometrical constraints.

\section{Experimental and FEM Procedure of RSW}

Throughout this research works, simulation of resistance spot welding process is being done simultaneously with the experiment to validate each of the result. FEA based, MSC.Marc sofware is used for the simulation while experimentally is done using Wimtouch 1800 Spot Welding Machine as shown in Fig. 5. tečenja, brzina ojačavanja i tri konstante koje određuju efekat ojačavanja pod uslovom za dalje tečenje [13]. Opšti oblik krive zavisnosti napona od stepena deformacije je izražen sledećom jednačinom $\sigma=A \varepsilon^{\wedge} \mathrm{n}$, pri čemu je $\mathrm{n}$ - koeficijent deformacionog ojačavanja, a A - konstanta koja je prilagođena da najbolje odgovara izmerenim vrednostima napon - deformacija. Vrednost $n$ treba da bude između nula i jedan da bi model imao konkavno - opadajuću krivu [14]. Model zavisnosti snage se koristi u velikoj meri zbog svoje matematičke jednostavnosti, međutim, na taj način se mogu modelirati samo određene vrste naprezanja.

Plastičnost se takođe može primeniti za analizu zaostalih napona i deformacija zavarenog spoja. $U$ tom slučaju, izlazne vrednosti prikazuju odnos između svojstvenih napona usled skupljanja materijala i zaostalih napona i deformacija zavarenog spoja. Ova analiza se može proširiti tako da obuhvati efekte početne deformacije, interakciju između susednih zavarenih spojeva, redosled zavarivanja, kao i krutost strukture. Da bi se koncept plastičnosti koristio u praktičnim situacijama, obično je potreban zavarivački test kalibracije, čime se definišu inženjerske vrednosti za karakteristične procesne parametre, nelinearnosti materijala i geometrijska ograničenja.

\section{Eksperimentalne i KME procedure elektrootpornog zavarivanja}

Tokom ovoga istraživanja, simulacija elektrootpornog tačkastog zavarivanja je izvršena uporedo sa eksperimentima, da bi potvrdili svaki rezultat. MKE je zasnovan na MSC.Marc programu koji je korišćen za simulaciju, dok su eksperimenti izvršeni na Wimtouch 1800 mašini za zavarivanje, što je prikazano na Slici 5.

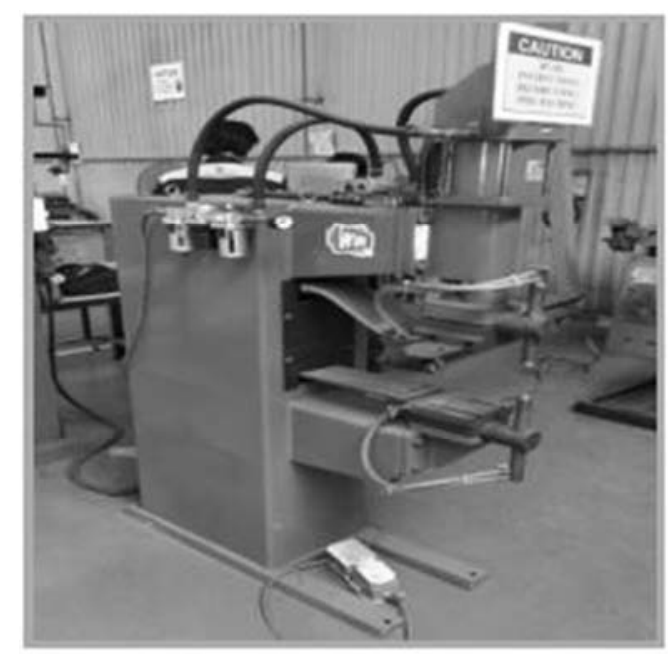

Figure 5. Wimtouch 1800 Spot Welding Machine

Slika 5. Wimtouch 1800 mašina za tačkasto zavarivanje 
Finite Element Analysis (FEA) approach was applied in the simulation of spot welding process which consists of 3 phases, pre-processing, solving and post-processing. The modelling of the geometry of the components are drawn directly in the MSC.Marc software.

The simulation procedure of RSW in MSC.Marc is shown in Fig. 6 below:
Analiza Konačnih Elemenata (MKE) je primenjena u simulaciji postupka tačkastog zavarivanja koji se sastoji od tri faze: preprocesiranja, rešavanja i postprocesiranja podataka. Modeliranje geometrije komponenata je izvršeno direktno u MSC.Marc programu. Simulacija procedure tačkastog zavarivanja u program MSC.Marc je prikazana na Slici 6:

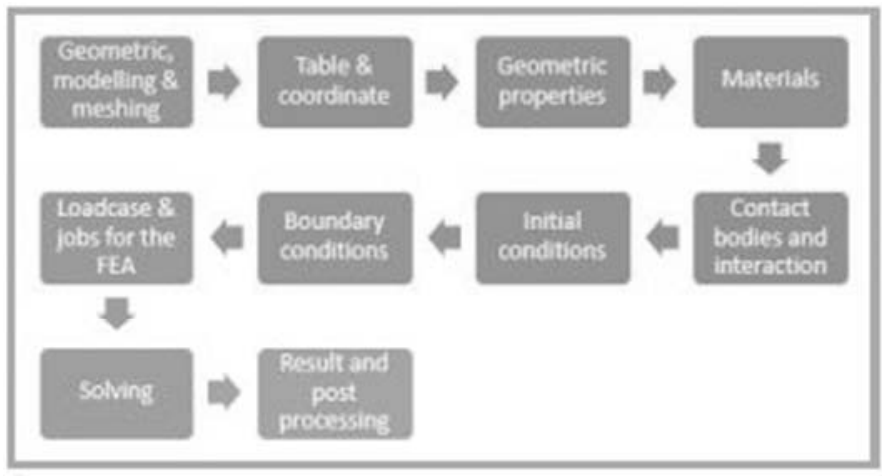

Figure 6. RSW simulation procedures using MSC.Marc

Slika 6. Procedura otpornog tačkastog zavarivanja koja koristi MSC.Marc program

Spot welding is governed by electrical-thermal, mechanical and metallurgical phenomena. The model takes the following physical and metallurgical interactions into consideration in the simulations: interaction between the electro-kinetics and heat transfer via the Joule effect, heat transfer and phase transformations through latent heat and heat transfer, electro-kinetics, and mechanical behaviour via contact conditions [15].

A three dimensional model consist of two sheets and two electrodes were modelled in MSC.Marc and dimensionally similar to the actual experimental procedure. MSC.Marc provides a three dimensional meshing with a tetrahedron shaped element. The accuracy of finite element model always depends on meshing. The mesh is graded from fine to coarse, according to the expected reduction in temperature gradient which moving away from the heat source [16]. Fig. 7 shows the modelling of RSW in MSC.Marc.
Tačkasto zavarivanje je određeno električnotermičkim, mehaničkim i metalurškim fenomenima. Korišćeni model uzima u obzir sledeće fizičke i metalurške interakcije u simulacijama: interakcija između elektro - kinetike i prenosa toplote pomoću Joul-ovog efekta, prenosa toplote $i$ faznih transformacija pomoću latentne toplote i prenosa toplote, elektro-kinetika i mehaničko ponašanje putem uslova na kontaktima [15].

Trodimenzionalni model u MSC.Marc programu se sastoji od dva radna predmeta i dve elektrode i dimenzionalno odgovaraju eksperimentalnom postupku. MSC.Marc pruža trodimenzionalno formiranje tetraedarske mreže. Tačnost modela bazirnih na metodi konačnih elemenata uvek zavisi od gustine mreže. Mreža je razvrstana od fine do grube, u skladu sa očekivanim smanjenjem temperaturnog gradijenta koji se udaljava od izvora toplote [16]. Slika 7 prikazuje modelovanje RSW u MSC.Marc.

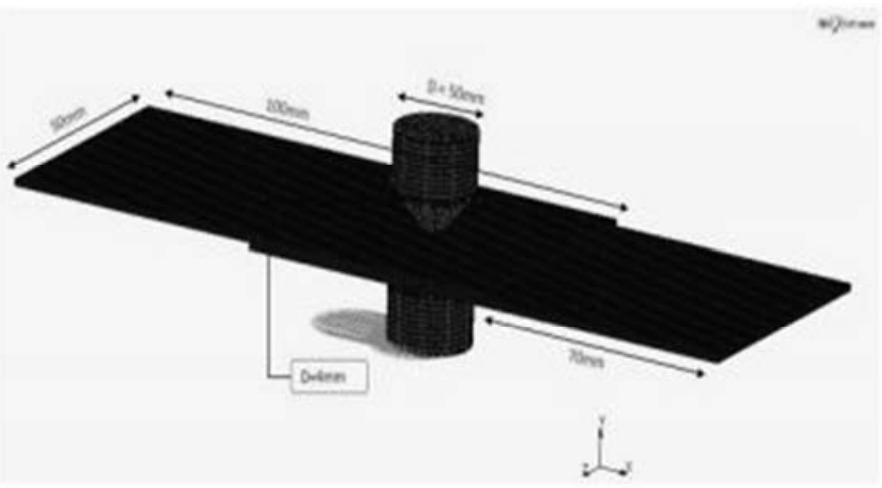

Figure 7. RSW modelling in MSC.Marc

Slika 7. Modeliranje otpornog tačastog zavarivanja u MSC.Marc programu 
For boundary condition in MSC.Marc software, it is necessary to be set up adequately to receive dependable outcomes. The boundary condition includes structural fixed displacement, structural point load (electrode force), thermal fixed temperature, current/thermal fixed voltage and current/thermal point current. At the top electrode, the electrical current was applied uniformly and flow to the tip of the electrode. Selection of the nodes for each boundary condition must be properly selected to prevent errors which could be associated to it.

In experimental study, low carbon steel material was used as the specimen based on several factors. The mechanical properties of the base metals were found using a spark emission machine and using a standard tensile test in conformity with ASTM E8M [17]. The chemical composition of the material is shown in Tab. 1 below while the dimension of the specimen is shown in Fig. 8. A standard size $100 \times 50 \times 1 \mathrm{~mm}$ for the base metal was prepared for experimental process according to AWS D8.9m [18]. However, in simulation, the geometry was created in the form of electrode and metal sheet only as the focus will be more towards the joining area.
Neophodno je odrediti odgovarajuće granične uslove u MSC.Marc softveru, da bi se dobili pouzdani rezultati. Granični uslov uključuju fiksno strukturno pomeranje, strukturno tačkasto opterećenje (sila elektrode), temperaturu, fiksirane struja/napon i struja/termička tačka vrednosti. Na gornjoj elektrodi električna struja je primenjena ravnomerno u pravcu vrha elektrode. Izbor nodalnih tačaka za svaki granični uslov mora biti pravilno odabran kako bi se sprečile greške.

$U$ eksperimentalnom istraživanju, kao uzorak je korišćen materijal od nisko-ugljeničnog čelika zbog nekoliko faktora. Mehaničke osobine određene su primenom standardnog ispitivanja zatezanjem $u$ skladu sa ASTM E8M, a hemijski sastav odrđen je optičkom emisionom spektroskopijom [17]. Hemijski sastav materijala prikazan je u Tabeli 1 , dok su dimenzije uzoraka prikazane na Slici 8. Standardna veličina $100 \times 50 \times 1 \mathrm{~mm}$ za bazni metal pripremljena je za eksperimentalni postupak prema AWS D8.9m [18]. Međutim, u simulaciji je geometrija kreirana samo za sklop elektrode i radnog predmeta, zato što je fokus usmeren na područje zavarenog spoja.

Table 1. S235 chemical composition (\%)

Tabela 1. S235 hemijski sastav (\%)

\begin{tabular}{|c|c|c|c|c|c|c|}
\hline $\mathrm{C}$ & $\mathrm{Cu}$ & $\mathrm{Fe}$ & $\mathrm{Mn}$ & $\mathrm{N}$ & $\mathrm{P}$ & $\mathrm{S}$ \\
\hline 0.15 & 0.4 & 98.293 & 1.1 & 0.01 & 0.02 & 0.027 \\
\hline
\end{tabular}
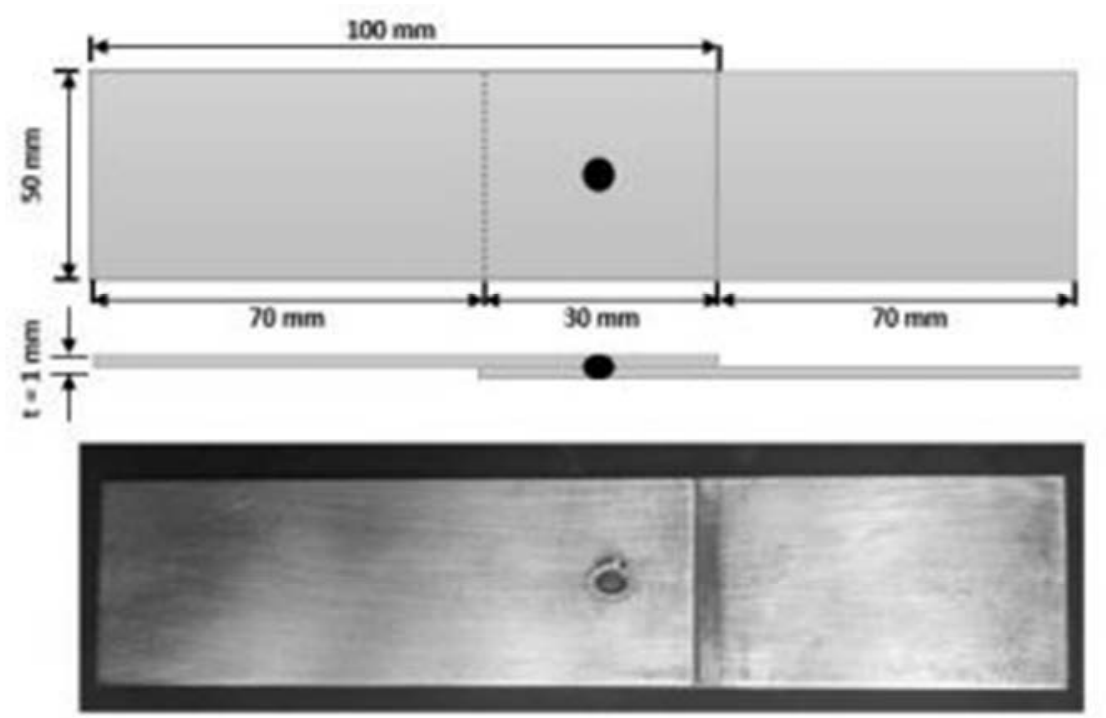

Figure 8. Dimension of the specimen

Slika 8. Dimenzije uzorka

Fig. 9 below shows the type of electrode used for the experiment which made of copper with truncated cone tips. The function of the electrode tips are for weld current to be conducted through the workpiece and form sufficient pressure for heat
Slika 9 prikazuje vrstu elektrode koja je korišćena za eksperiment, koja je izrađena od bakra sa skraćenim konusnim vrhovima. Funkcija vrhova elektroda je da se struja zavarivanja provodi kroz radni predmet i formira dovoljan pritisak radi 
to be generated at the spot welded point. The tips must maintain their integrity of shape and characteristics of thermal and electrical conductivity under working conditions. The diameter of the electrode tip that was used is $4 \mathrm{~mm}$. Same geometry of the electrode is then modelled in the simuation. stvaranja toplote na mestu zavarenog spoja. Pod radnim uslovima vrhovi moraju održavati integritet oblika i date toplotne i električne karakteristike provodljivosti. Prečnik vrha elektrode od $4 \mathrm{~mm}$ je korišćen. Ista geometrija elektrode je korišĆena u simulaciji.

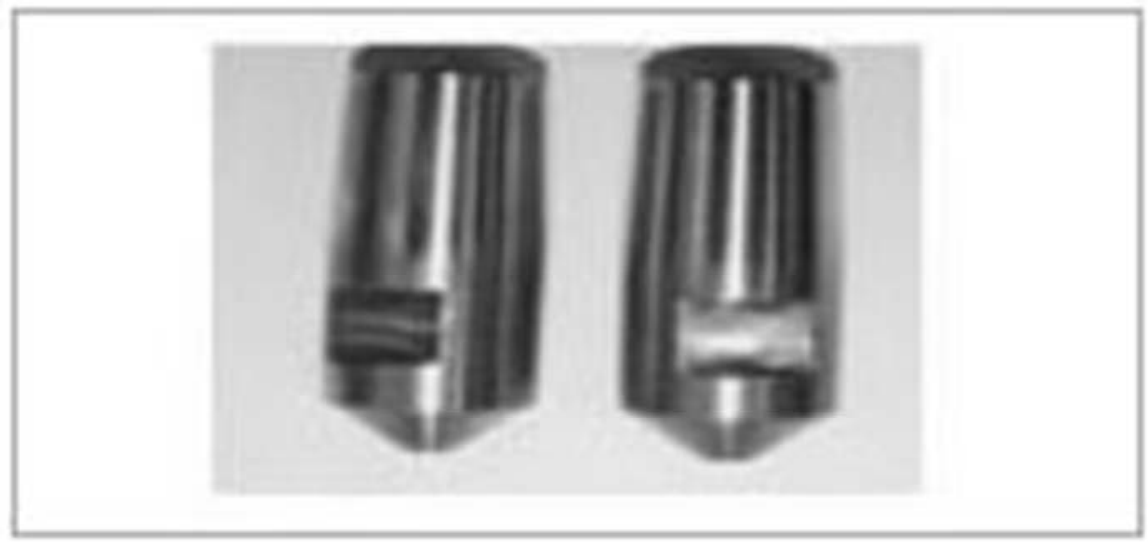

Figure 9. Truncated cone electrode tip

Slika 9. Vrh skraćene konusne electrode

\subsection{Welding Parameters}

Tab. 2 below shows the parameter used for the spot welding process during the experiment. The spot welding was carried out to four specimens with same parameters except the weld current.

\subsection{Parametri zavarivanja}

Tabela 2 prikazuje parametre koji se koriste za proces tačkastog zavarivanja tokom eksperimenta. Tačkasto zavarivanje izvedeno je na četiri uzorka sa istim parametrima, osim struje zavarivanja.

Table 2. Welding parameter at different levels

Tabela 2. Parametri zavarivanja na različitim nivoima struje zavarivanja

\begin{tabular}{|c|c|c|c|c|c|}
\hline $\begin{array}{c}\text { Welding Parameter } \\
\text { Parametri } \\
\text { zavarivanja }\end{array}$ & $\begin{array}{c}\text { Unit } \\
\text { Jedinica }\end{array}$ & $\begin{array}{c}\text { Level 1 } \\
\text { Nivo 1 }\end{array}$ & $\begin{array}{r}\text { Level 2 } \\
\text { Nivo 2 }\end{array}$ & $\begin{array}{c}\text { Level 3 } \\
\text { Nivo 3 }\end{array}$ & $\begin{array}{c}\text { Level 4 } \\
\text { Nivo 4 }\end{array}$ \\
\hline $\begin{array}{c}\text { Electrode force } \\
\text { Pritisak elektroda }\end{array}$ & $\mathrm{kN}$ & 5 & 5 & 5 & 5 \\
\hline $\begin{array}{c}\text { Squeeze time } \\
\text { Vreme stiska }\end{array}$ & Cycle & 25 & 25 & 25 & 25 \\
\hline $\begin{array}{c}\text { Weld time } \\
\text { Vreme zavarivanja }\end{array}$ & Cycle & 17 & 17 & 17 & 17 \\
\hline $\begin{array}{c}\text { Hold time } \\
\text { Vreme držanja }\end{array}$ & Cycle & 10 & 10 & 10 & 10 \\
\hline $\begin{array}{c}\text { Weld current } \\
\text { Struja zavarivanja }\end{array}$ & kA & 6 & 8 & 10 & 15 \\
\hline
\end{tabular}

\subsection{Tensile Test}

At different parameters, there will be different tensile strength value [19]. As such, perfect

\subsection{Ispitivanje zatezanjem}

Pri različitim parametrima dobijaju se različite vrednosti zatezne čvrstoće [19]. Određivanje savršenih kombinacija parametara je važno radi 
combination of parameters is important to achieve expected tensile shear strength. Fig. 10 below shows the Instron 3382 model machine which was used in conducting the tensile test on the specimen. This machine is ideal for tension and/or compression applications for test up to $100 \mathrm{kN}$ load and provides simplicity, reliability, and affordability for product testing. Meanwhile, in simulation, tensile test was conducted after the spot welding and cooling process. Top sheet was set to fixed in all directions while the bottom sheet is stretched. postizanja očekivanih zateznih smicajnih čvrstoća. $\mathrm{Na}$ slici 10 prikazana je mašina modela Instron 3382 koja je korišćena za ispitivanje zatezanjem. Ova mašina je idealna za ispitivanja zatezanja i/ili pritiska za opterećenja do $100 \mathrm{kN}$ jer pruža jednostavnost, pouzdanost i pristupačnost ispitivanja uzoraka. Simulurano je ispitivanje zatezanjem nakon tačkastog zavarivanja i hlađenja. Gornja ploča je fiksirana u svim pravcima, dok se donja ploča zateže.

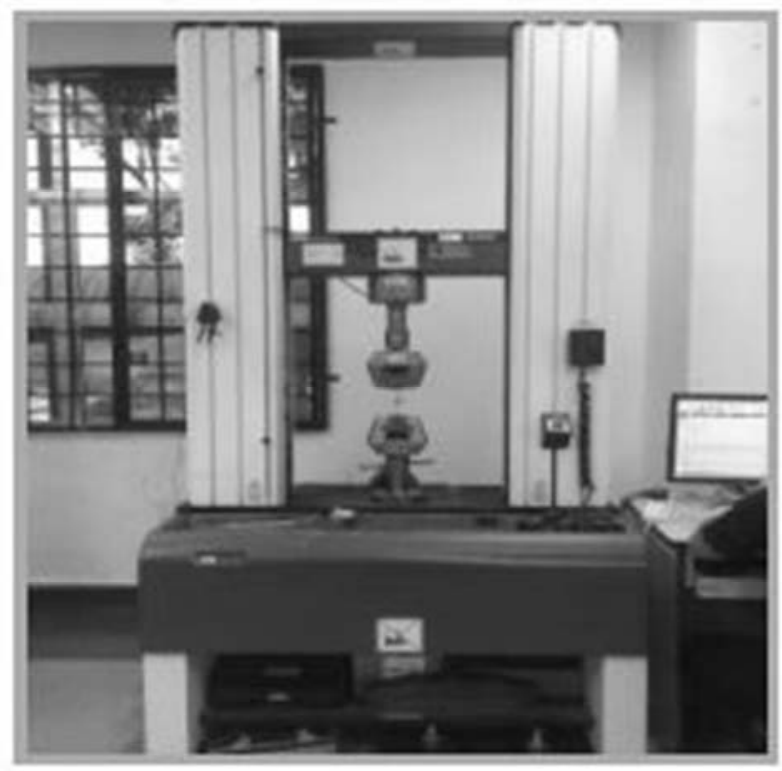

Figure 10. Instron 3382 Machine

Slika 10. Mašina Instron 3382

Prior to conducting the tensile test, the specimen is prepared and the dimension is recorded. Subsequently, the specimen is clamped tightly at both end and run at constant speed of 5 $\mathrm{mm} /$ minute. The tensile shear test procedure is shown in Fig. 11 below.
Pre izvođenja ispitivanja zatezanjem, uzorak je pripremljen i ubeležene su dimenzije. Zatim je uzorak čvrsto stegnut na oba kraja i zatezanje je vršeno konstantnom brzinom od $5 \mathrm{~mm} /$ minutu. Postupak ispitivanja smicajnog naprezanja je prikazan na Slici 11.

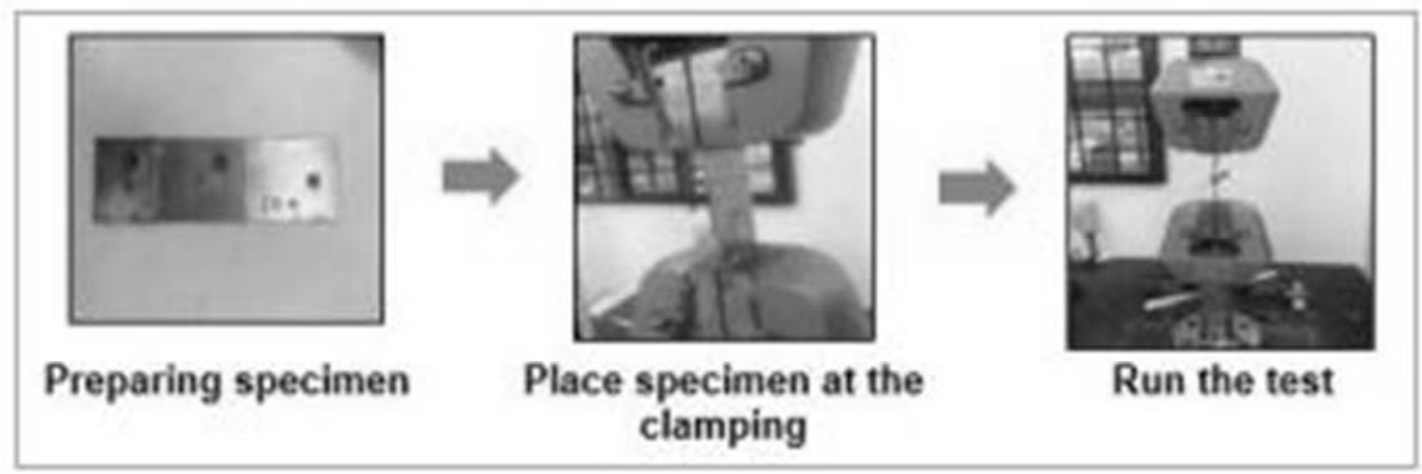

Figure 11. Tensile test procedures

Slika 11. Procedura ispitivanja zatezanjem

\section{Result and Discussion}

In this research, simulation of resistance spot welding was carried using FEA based software,

\section{Rezultati i diskusija}

U ovom istraživanju izvršena je simulacija tačkastog zavarivanja pomoću MSC.Marc softvera zasnovanog na MKE. Podaci korišćeni u simulaciji 
MSC.Marc. The data used in the simulation for the geometry and materials is conform with the experimentation. The simulation was run at different values of weld current which is at $6 \mathrm{kA}$, $8 \mathrm{kA}, 10 \mathrm{kA}$ and $15 \mathrm{kA}$. Both simulation and experiment were carried out until the tensile test to develop better understanding on the effect selected parameters to the tensile strength of a spot welded joint.

\subsection{Plasticity}

The essential problem in the solution of a plasticity problem is to determine how stresses and strains can be found for a specified state of loading on a body. Plasticity used in this simulation involving Piecewise Linear for strain rate method. Material used in the simulation is initially isotropic and fulfills the maximum shear stress initial yield condition. The stress-strain curves were represented using Power Law model equation. za geometriju i materijale u skladu su sa eksperimentalnom postavkom. Simulacija je izvedena pri različitim vrednostima struje zavarivanja koja iznosi 6 kA, 8 kA, 10 kA i 15 kA. Simulacija i eksperiment su korišćeni kako bi se ostvarilo bolje razumevanje efekata izabranih parametara na zateznu čvrstoću tačkasto zavarenog spoja.

\subsection{Plastičnost}

Suštinski problem $u$ rešavanju problema plastičnosti je kako utvrditi veličinu napona i deformacija opterećenog tela. Plastičnost korišćena u ovoj simulaciji koristi metodu linearne zavisnosti za određivanje stepena zatezanja. Materijal korišćen $u$ simulaciji je $u$ početku izotropan i ispunjava početni uslov maksimalnog naprezanja na smicanje. Krive naprezanje-deformacija su predstavljene pomoću stepene jednačine.

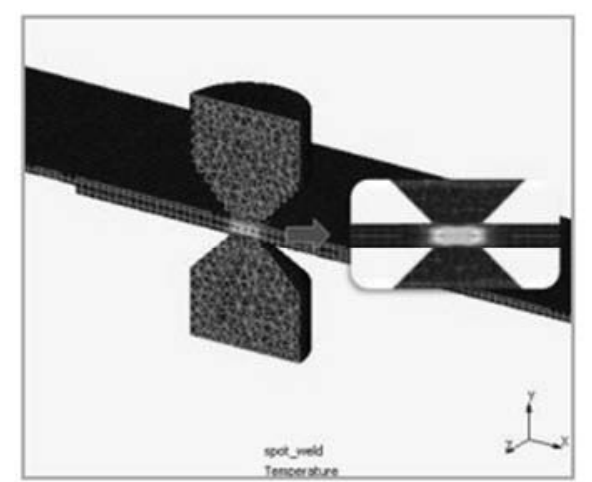

Figure 12. Weld nugget formation in simulation

Slika 12. Formiranje sočivastog šava zavarenog spoja pri simulaciji

A modification of Ohm's Law can be made when watts and heat are considered synonymous. When current is passing through a conductor the electrical resistance exist between the conductor will cause the heat to be generated. Fig. 12 above shows the temperature profile of spot welding process in simulation. The nugget was formed in the region of peak temperature. In spot welding, the heat generated is directly proportional to the welding current.

\subsection{Contact Resistance/ Conductance}

In the simulation of resistance spot welding, electrical contact resistance or conductance is one of important element to be considered and the data will have significant effect to the result of the simulation. Fig. 13 below shows the resistances which exists during the spot welding process.
Modifikacija Omovog zakona može se izvršiti ako se jedinice vat i toplota posmatraju kao sinonimi. Kada struja prolazi kroz provodnik, električni otpor između provodnika će dovesti do stvaranja toplote. Slika 12 prikazuje temperaturni profil simuliranog tačkastog zavarivanja. Sočivasti šav je nastao u predelu najviše temperature. Pri tačkastom zavarivanju, proizvedena toplota je direktno proporcionalna struji zavarivanja.

\subsection{Otpor/provodljivost kontakta}

U simulaciji otpornog tačkastog zavarivanja, otpor na električnim kontaktima i provodljivost su važni elemenati koje treba uzeti u obzir, čiji podaci imaju značajan uticaj na rezultate simulacija. Slika 13 prikazuje otpore tokom postupka tačkastog zavarivanja. 


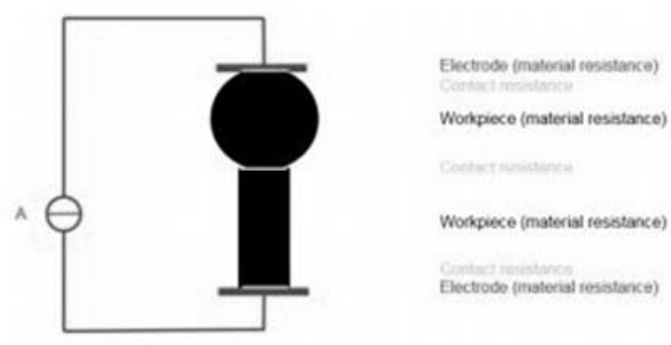

Figure 13. Resistance in Spot Welding Process

Slika 13. Otpor u procesu tačkastog zavarivanja

The contact resistance can be expressed with the following equation:

$R=\rho I / A$

Where $\mathrm{R}$ is the electrical contact resistance, $\rho$ is the electrical contact resistivity, $I$ is the film thickness of the contact area and $A$ is the contact area. In MSC.Marc electrical contact conductance is used instead of contact resistance. However, electrical contact conductance is the reciprocal of the electrical resistance. In most cases the electrical contact resistance is 30 times larger than the electrical material resistance. Electrical material resistance and electrical contact resistance are strongly depending on temperature. Additionally the electrical contact resistance is also depending on contact pressure. During the welding process the electrical contact resistance decreases rapidly whereas the electrical material resistance increases. Fig. 14 below shows the curves of electrical material resistance, electrical contact resistance and the complete resistance of the system during resistance spot welding process:
Otpor kontakta može se izraziti sledećom jednačinom:

$R=\rho I / A$

gde je $R$ otpor električnog kontakta, $\rho$ otpor električnog kontakta, $I$ je debljina filma površine kontakta, dok je A površina kontakta. U MSC.Marc programu se koristi električna kontaktna provodljivost umesto kontaktnog otpora. Međutim, provodljivost električnog kontakta je recipročna vrednost električnog otpora. U većini slučajeva otpor električnog kontakta je 30 puta veći od otpora električnog materijala. Otpori električnog materijala i kontakta značajno zavise od temperature. Pored toga, električni otpor kontakta zavisi od pritiska kontakta. Tokom postupka zavarivanja otpor električnog kontakta se brzo smanjuje, dok se otpor električnog materijala povećava. Slika 14. prikazuje krive otpora električnog materijala, otpora električnog kontakta i ukupnog otpora sistema tokom postupka tačkastog zavarivanja:

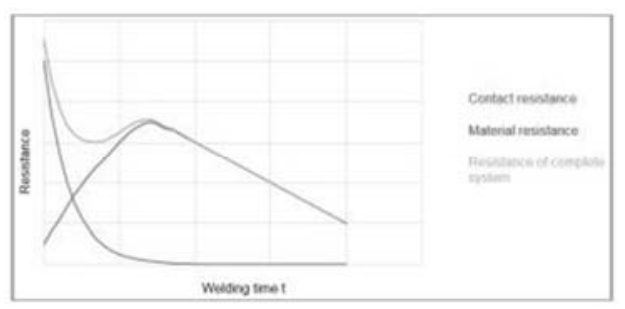

Figure 14. Time curves for electrical resistances during spot welding process

Slika 14. Vremenske krive za električni otpor tokom procesa tačkastog zavarivanja

\subsection{Tensile test in experiment}

Experiment process was conducted simultaneously with the simulation. Specimens were spot welded according to selected parameters followed with tensile shear test to obtain the results. Tab. 3 below shows the results of the tensile shear test. The specimen with highest Ultimate Tensile Strength (UTS) is with optimum weld current parameter for the spot welding process.

\subsection{Eksperimentalno određivanje zatezne čvrstoće}

Eksperimenta je izveden istovremeno sa simulacijom. Uzorci su tačkasto zavareni prema odabranim parametrima, praćeni ispitivanjem smicajnim zatezanjem. Tabela 3 prikazuje rezultate ispitivanja smicajnog zatezanja. Uzorak sa najvećom zateznom čvrstoćom ima optimalni parametar struje zavarivanja tokom postupka tačkastog zavarivanja. 
Table 3. Tensile test result on the specimen

Tabela 3. Rezultati ispitivanja zatezanjem na uzorcima

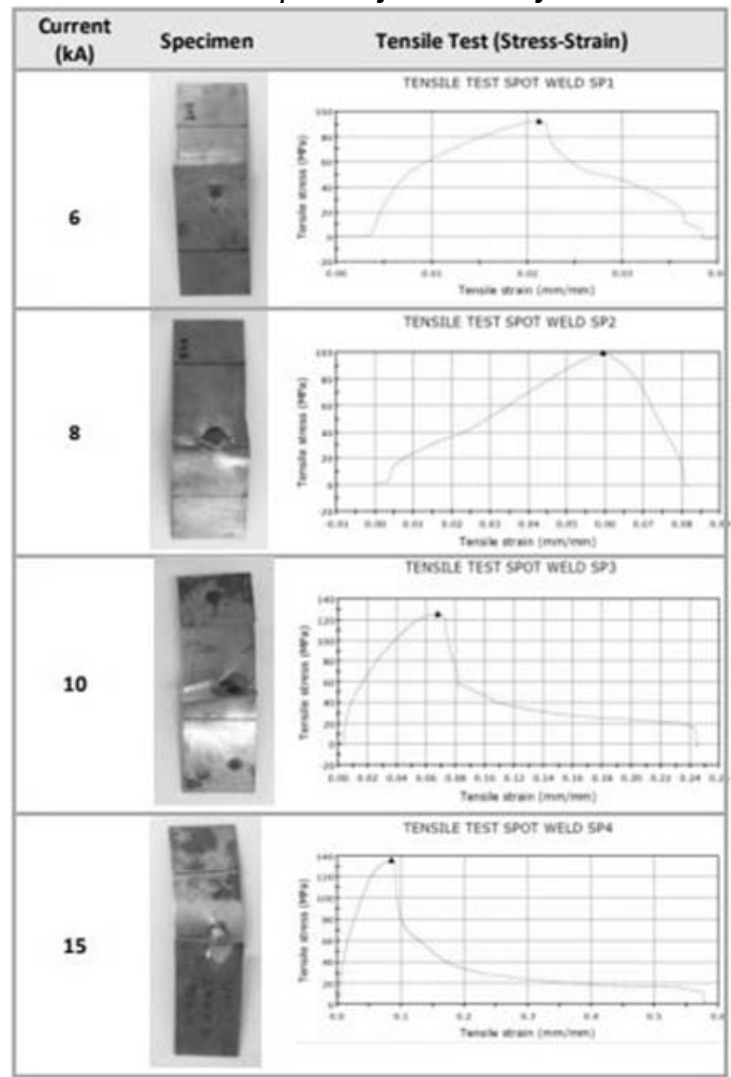

Table 4. Tensile test stress at maximum load

Tabela 4. Zatezna čvrstoća pri maksimalnom opterećenju

\begin{tabular}{|c|c|c|}
\hline $\begin{array}{c}\text { Welding current } \\
\text { Struja zavarivanja } \\
(\mathrm{kA})\end{array}$ & $\begin{array}{c}\text { Tensile stress at max. } \\
\text { load } \\
\text { Zatezna čvrstoća pri } \\
\text { max. opterećenju } \\
\text { (MPa) }\end{array}$ & $\begin{array}{c}\text { Load } \\
\text { Opterećenje } \\
(\mathrm{N})\end{array}$ \\
\hline 6 & 511.520 & $6,427.946$ \\
\hline 8 & 565.103 & $7,101.078$ \\
\hline 10 & 617.593 & $7,760.669$ \\
\hline 15 & 735.592 & $9,243.723$ \\
\hline Min. & 511.520 & $6,427.946$ \\
\hline Max. & 735.592 & $9,243.723$ \\
\hline
\end{tabular}

From the Tab. 4 above, the maximum tensile stress which was recorded at $735.592 \mathrm{MPa}$ and the maximum load is $9,243.723 \mathrm{~N}$ which is for $15 \mathrm{kA}$ of weld current while the minimum tensile stress is $511.520 \mathrm{MPa}$ and minimum load is $6,427.946 \mathrm{~N}$ of $6 \mathrm{kA}$. Thus, the highest maximum load recorded is obtained from the weld current of $15 \mathrm{kA}$.

\subsection{User Subroutine and tensile test in simulation}

Prior to running the simulation, load cases have to be created in order for the defined job parameter to
Iz Tabele 4, maksimalna zatezna čvrstoća je zabeleženo na $735.592 \mathrm{MPa}$, a maksimalno opterećenje je 9.243.723 N, što odgovara intezitetu struje zavarivanja od $15 \mathrm{kA}$, dok je minimalna zatezna čvrstoća $511.520 \mathrm{MPa}$, a minimalno opterećenje 6.427.946 N za 6 kA. Dakle, najveće zabeleženo maksimalno opterećenje dobija se kod struje zavarivanja od $15 \mathrm{kA}$

\subsection{Podprogram korisnika $i$ ispitivanje} zatezanjem pri simulaciji

Pre izvođenja simulacije, načini opterećenja moraju se formirati kako bi se definisali parameti koji će se primeniti. Izrađena su tri slučaja opterećenja koja 
be applied. 3 load cases were created which consists of welding, cooling and tensile test.

Fig. 15(a) shows the contact condition between each of the components, top electrode, top sheet, bottom sheet and bottom electrode. Each of the components must be in contact to each other to ensure the activation of contact resistance and allow sufficient of heat to be generated when the weld current is applied during the welding process. Electric potential result as shown in Fig. 15(b) indicates the current flow through the top electrode, specimen and bottom electrode. The point current was applied at the top surface of the top electrode while zero voltage is set at the lower surface of the bottom electrode.

Fig. 15(c) The grey color region shows the nugget formation during the resistance spot welding process. The peak temperature is also used to define the fusion zone with application of UACT GLUE user subroutine. Glue deactivation will be activated to all the selected nodes between the two sheets except the nodes that reach the predefined glued temperature.

Fig. 15(d) shows the application of tensile load after the welding and cooling process. High stress region was observed after tensile shear load is applied. se sastoje od zavarivanja, hlađenja i ispitivanja zatezanjem.

Slika 15(a) prikazuje stanje kontakta između svake od komponenata, gornje elektrode, gornje ploče, donje ploče i donje elektrode. Svaka od komponenata mora biti u međusobnom kontaktu, kako bi se osiguralo aktiviranje otpora kontakta i omogućilo stvaranje dovoljne toplote tokom postupka zavarivanja dok se primenjuje struja zavarivanja. Rezultat električnog potencijala, kao što je prikazano na slici 15(b) ukazuje na protok struje kroz gornju elektrodu, uzorak i donju elektrodu. Ciljana struja primenjena je na gornjoj površini gornje elektrode, dok je nulti napon podešen na donjoj površini donje elektrode.

$\mathrm{Na}$ slici 15(c) oblast sive boje pokazuje stvaranje vara tokom procesa tačkastog zavarivanja. Vršna temperatura se takođe koristila za definisanje zone stapanja primenom korisničkog potprograma UACT GLUE. Glue deaktivacija je aktivirana na svim izabranim nodalnim čvorovima između dve ploče, osim na nodalnim čvorovima koji dostignu unapred definisanu temperature spajanja. Slika 15(d) prikazuje primenu zateznog opterećenja nakon završetka procesa zavarivanja i hlađenja. Područje visokih naprezanja primećeno je nakon primene zateznog smicajnog naprezanja.

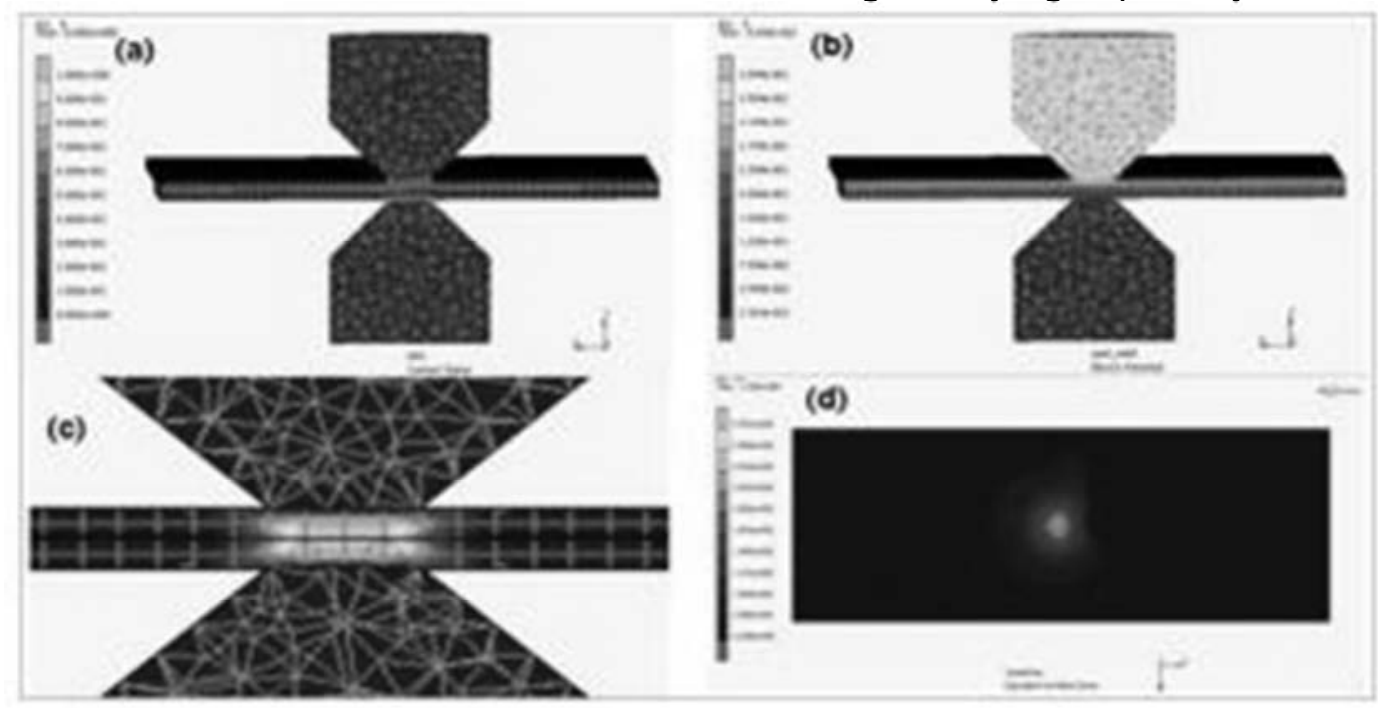

Figure 15. (a) Contact status, (b) Electric potential (c) weld nugget,(d) Equivalent von-misses stress regio

Slika 15. (a) Status kontakata, (b) električni potencijal, (c) sočivast zavareni spoj, (d) Ekvivalent oblasti naprezanja

As the material melting temperature in simulation may vary compared with the actual experiment, nugget size formed in the experiment will be used as reference to determine acceptable temperature to define the glued region of spot welded joint in simulation. This reverse process is practical to analyze the differences between experimental and simulation. The measurement of the weld nugget is shown in Fig. 16 below.
Kako se temperatura topljenja materijala $u$ simulaciji može razlikovati u poređenju sa stvarnim eksperimentom, veličina zavarenog spoja formirana u eksperimentu koristiće se kao referenca za određivanje prihvatljive temperature za definisanje spojenog područja tačkasto zavarenog spoja u simulaciji. Ovaj obrnuti postupak je praktičan za analizu razlika između eksperimentalnih i simuliranih rezultata. Merenje zavarenog spoja je prikazano je na Slici 16. 


\section{Nugget size experiment}

\section{Glued rezion in simulation}

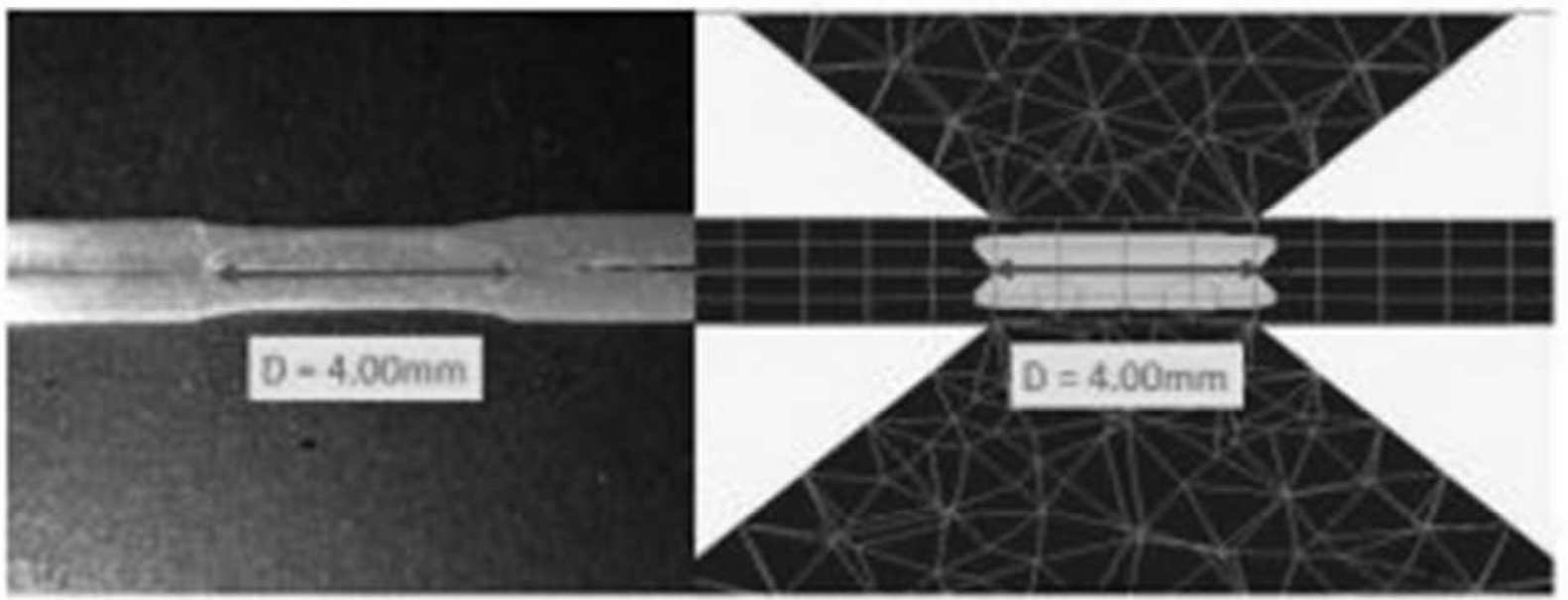

Figure 16. Nugget size measurement

Slika 16. Merenje veličine sočivastog zavarenog spoja

The temperature was observed at $800^{\circ} \mathrm{C}$ for $4 \mathrm{~mm}$ weld nugget diameter to be formed at the contact surface. Through this information, the glued region temperature was set $>800^{\circ} \mathrm{C}$ in the subroutine.
Konstatovana je temperatura od $800^{\circ} \mathrm{C}$ за prečnik spoja od $4 \mathrm{~mm}$ koji se formira na kontaktnoj površini. Na osnovu ove informacije u potprogramu je podešena temperature radnog područja $>800^{\circ} \mathrm{C}$.

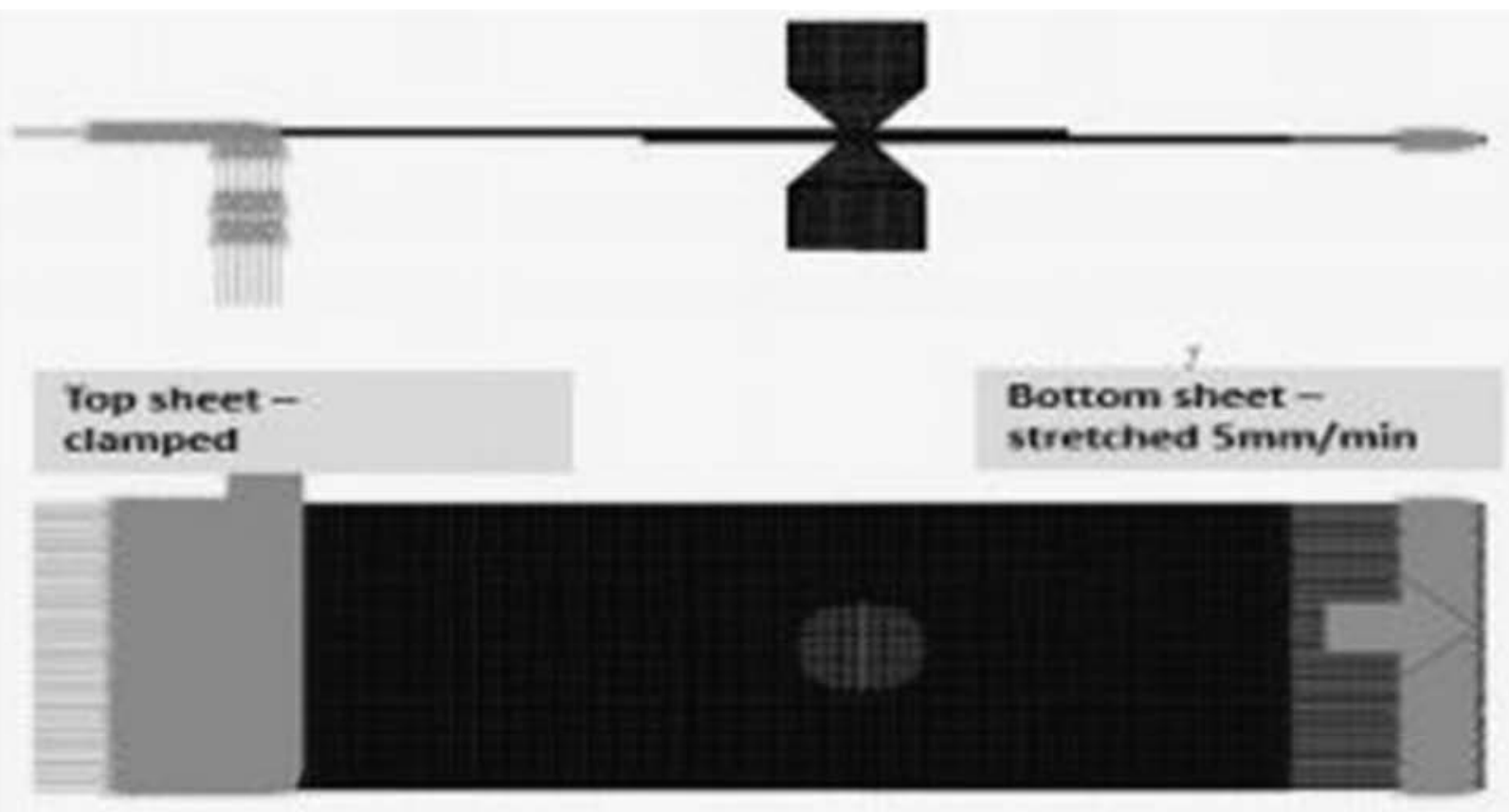

Figure 17. Tensile modelling in simulation

Slika 17. Modeliranje zatezanja pri simulaciji

Fig. 17 above shows the tensile shear test which has been modelled in the simulation. To set up the test, one of the sheet is clamped by applying fix displacement in $x, y, z$ axis and the other sheet is subjected to contact clamp velocity of $5 \mathrm{~mm} / \mathrm{min}$.

Fig. 18 below shows the result of tensile test for one of the specimens in experiment compared with simulation. Under tensile shear load, both specimen in experiment and model in simulation was observed experienced bending at the region
Slika 17 prikazuje test smicajnog zatezanja koji je modelovan pri simulaciji. Da bi se postavo test, jedana od ploča se fiksira u $x, y, z$ osama, a druga ploča je podvrgnuta pomeranju kontaktne stezaljke brzinom od $5 \mathrm{~mm} / \mathrm{min}$.

Slika 18 prikazuje rezultat poređenja ispitivanja zatezanjem i simulacijom za jedan od uzoraka. Pod opterećenjem smicajnim zatezanjem, primećeno je da su oba uzorka, i u eksperimentu i u simulaciji, pretrpeli savijanje u predelu blizu vara. Međutim, 
close to the weld nugget. However, deformation profile for each of the specimen may vary subjected to the parameter applied and condition prior to the tensile i.e. residual stress or distortation may exist after the spot welding process.

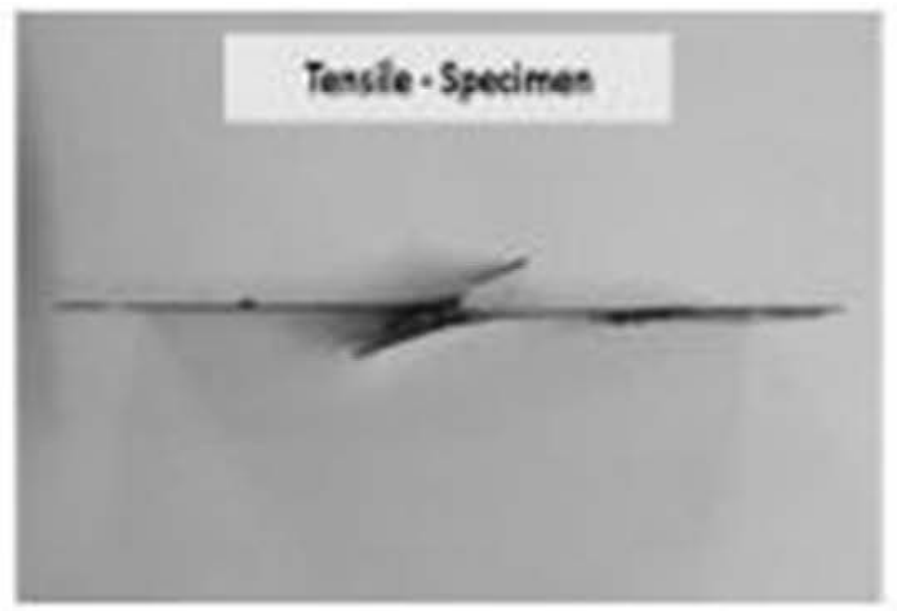

profil deformacije za svaki uzorak može se razlikovati u zavisnosti od primenjenog parametra i stanja pre naprezanja, odnosno mogu postojati zaostala naprezanja ili izobličenja nakon postupka tačkastog zavarivanja.

Figure 18. Result of tensile test of specimen vs simulation Slika 18. Rezultati zateznih ispitivanja uzoraka $i$ simulacije

\section{Conclusion}

This study is focusing on analysis of resistance spot welding by simulation to be validated through experimental approach. Tensile shear test is a well known characteristics to determine the tensile strength of material especially in a spot welded joint. Same process parameters were applied in the simulation to study the differences with experiment result. The result obtained satisfies early theoretical assumption that certain process parameter such as weld current, contact condition and boundary condition were highly influential. However, further study is required to establish deeper understanding on the effect of each process parameter to the strength of the spot welded joint as follows:

- Developing clearer scope of damage criteria to be applied in simulation to achieve result similar with experimental approach.

- Application of scanning electron microscope (SEM) to obtain a fuller apprehension of the phases of the welded zone and development of the weld nugget.

- Analyzing the thermal and phase transformation of RSW

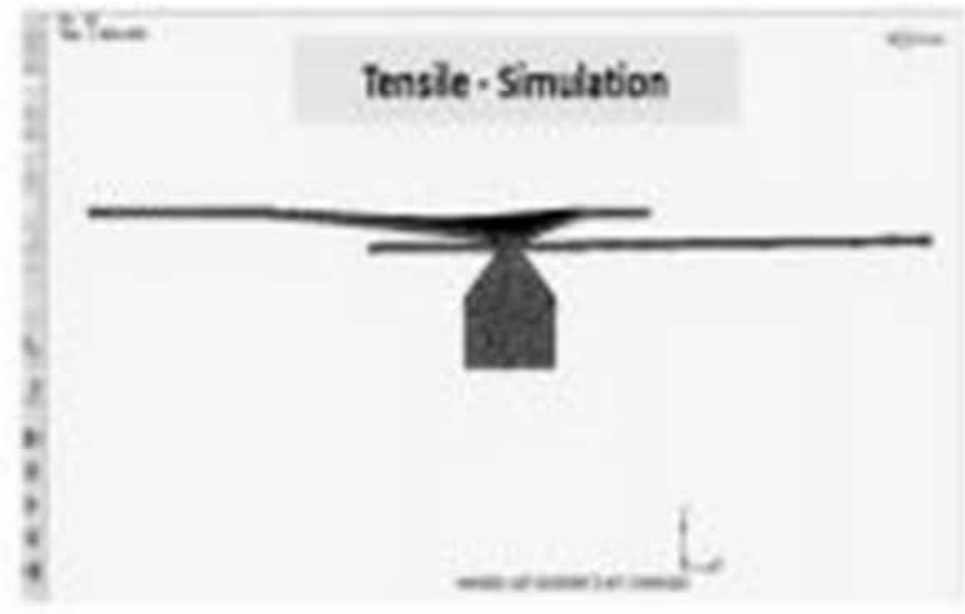

\section{Zaključak}

Ova studija je fokusirana na analizu elektrootpornog tačkastog zavarivanja simulacijom, koja je potvrđena eksperimentalnim pristupkom. Ispitivanje smicajnim zatezanjem je dobro poznata metoda određivanja zatezne čvrstoće materijala, posebno u tačkasto zavarenom spoju. Isti procesni parametri su primenjeni u simulaciji, radi proučavanja razlika sa eksperimentalnim rezultatima. Dobijeni rezultati zadovoljavaju prvobitnu teorijsku pretpostavku da su određeni procesni parametri veoma značajni, kao što su struja zavarivanja, kontaktni uslovi i granični uslovi. Međutim, potrebna su dalja proučavanja kako bi se utvrdilo dublje razumevanje uticaja svakog procesnog parametra na čvrstoću tačkasto zavarenog spoja i to:

- Razvijanje jasnijeg kritičnog nivoa, koji će se primeniti u simulaciji, kako bi se postigao rezultat sličan eksperimentalnom pristupu.

- Primena skenirajućeg elektronskog mikroskopa (SEM), za postizanje potpunijeg razumevanja postojećih faza u zavarenoj zoni i razvoj sočivastog zavarenog spoja.

- Analiza toplotnih i faznih transformacije pri elektrotpornom tačakastom zavarivanju. 


\section{Acknowledgement}

The authors would like to express their gratitude to staff member of Research Interest Group: Advanced Manufacturing Technology and Advanced Manufacturing Technology Excellence Centre at Faculty of Mechanical Engineering, Universiti Teknologi MARA (UiTM) for encouraging this research. This research and conference participation is also financially supported by ASEAUNINET grant with the project number ASEA 2019/Montan/1.

\section{References}

[1] Joel Andersson, Jonatan Deleskog, Fatigue Life and Stiffness of the Spider Spot Weld Model, Master's thesis, ISSN 1652-8557, 2014:22

[2] Ario Sunar Baskoro, M. Rizky Trianda, Jos Istiyanto, Sugeng Supriyadi, Danardono A. Sumarsono, Gandjar Kiswanto, Effects of Welding Time and Welding Current to Weld Nugget and Shear Load on Electrical Resistance Spot Welding of Cold Rolled Sheet for Body Construction, 2014 IEEE International Conference.

[3] Sachin Patil, Hamid Lankarani, Characterization and Simplified Modeling of the Failure Behavior of Spot Welds from Extra-High Strength Steels for Crash Simulation, Volume 16 Issue 4 Version 1.0, Year 2016 [4] László Prém, Zoltán Bézi and András Balogh, Development of Complex Spot Welding Technologies for Automotive DP Steels with FEM Support, DOI 10.1007/978-3-319-51189-4_36, International Publishing AG $\mathbf{2} 017$

Springer

[5] Szabolcs Szávai, Zoltán Bézi, Experimental and numerical analysis of resistance spot welded joints on DP600 sheets, January 2014

[6] Aditya S. Kulkarni, Dr. K. H. Inamdar, Effect of Process Parameters on Resistance Welding, April 2015, Volume 2, Issue 4

[7] Miller Technical Handbook for Resistance Spot Welding, 2012-003 335D

[8] Ikram Ali, M.I Khan, K.M.Moeed, Comparative Study of Spot Welding Process Parameters on Microstructure and Mechanical Properties of ASS 304 and ASS 202 Steel, Vol. 3, Issue 1, pp: (35-39), 2015 [9] Kamran Rasheed,M.I.Khan, "A Review on different optimization techniques used to optimize the process parameters of resistance spot welding", International Journal of Engineering Technology,Management, and Applied Sciences, page 2,October 2014,Volume 2 Issue 5,ISSN 2349-4476.

\section{Zahvalnica}

Autori žele da izraze zahvalnost članu istraživačke grupe: Napredne proizvodne tehnologije i Centar izvrsnosti napredne proizvodne tehnologije na Mašinskom fakultetu Univerziteta Tehnologije MARA (UiTM) na podsticanju ovog istraživanja. Ovo istraživanje i učešće na konferencijama takođe finansijski podržava ASEAUNINET grant sa brojem projekta ASEA 2019/Montan/1

[10] Zoha Nasir, Dr.M.I.Khan "Resistance spot welding and optimization techniques used to optimize its process parameters", International Research Journal of Engineering and Technology (IRJET).

[11] Sun, D., Zhang, Y., Liu, Y., Gu, X., \& Li, H. (2016). Microstructures and mechanical properties of resistance spot welded joints of $16 \mathrm{Mn}$ steel and 6063T6 aluminum alloy with different electrodes. JMADE, 109, 596-608.

[12] Dickinson, D. W, Franklin, J. E. and Stanya, A. Characterization of spot welding behavior of dynamic electrical parameter monitoring. Weld. J., 1980,59 (6), 170s-176s.

[13] P. G. Hodge, Jr."A General Theory of Piecewise Linear Plasticity Based on Maximum Shear" Journal of the Mechanics and Physics of Solids, 1057, Vol. 5, pp. 242 to 260.

[14] Okerblom, H.O.,"calculations of Deformations of Welded Structures, MASHGIZ, Moscow, 1955.

[15] M. Eshraghi, M.A. Tschopp, M.A. Zaeem, S.D. Felicelli. "Effect of resistance spot welding parameters on weld pool properties in a DP600 dual-phase steel: A parametric study using thermomechanically-coupled finite element analysis", Materials and Design (2014) Vol. 56, pp. 387- 397.

[16] Y. P. Yang, S. S. Babu, F. Orth, W. Peterson "Integrated computational model to predict mechanical behavior of spot weld", Science and Technology of Welding and Joining, 2008 Vol. 13 No. 3.

[17] Gerhardt RA. "Impedance Spectroscopy and Mobility Spectra" Encyclopedia of Condensed Matter Physics. London: Elsevier; 2005. p. 350-63.

[18] AWS. Standard test method AWS D8.9M (Recommended Practices for Test Methods for Evaluating the Resistance Spot Welding Behavior of Automotive Sheet Steel Materials). 2012.

[19] Lebbal Habib, Ziadi Abdelkader, Berrekia Habib, Boukhoulda Farouk Benallel "Experimental Study of Tensile Test in Resistance Spot Welding Process", Latin American Journals of Solids and Structures. 